\title{
Effect of Planting Dates and Silicon Foliar Application on Soybean Productivity
}

\author{
Kandil $^{1}$, E.E., A. A. Farag ${ }^{2}$ and M. I.A El-Shabory ${ }^{2}$ \\ ${ }^{1}$ Plant Production Department, The Faculty of Agriculture, Saba Basha, Alexandria \\ University, Egypt. \\ ${ }^{2}$ Central Laboratory for Agricultural Climate, Agriculture Research Center (ARC), \\ Egypt.
}

\begin{abstract}
The present study was carried out at the experimental Farm of Agriculture Research Station, Itay El-Baroud, EL-Behiera Governorate, Egypt, during the two summer seasons of 2017 and 2018 to study the effect of the three planting dates $1^{\text {st }}, 20^{\text {th }}$ May and $10^{\text {th }}$ June and foilar application of silicon at the rate of $(100,200,300 \mathrm{mg} / \mathrm{L}$ and water spray = control) on yield and quality of soybean cv. Giza 111. This experiment was laid out in split plot design with three replications. The three planting dates were distributed in main plots, while the four silicon concentration were allocated in the sub plots. The obtained results showed that planting soybean during May $1^{\text {st }}$ and $20^{\text {th }}$ exceeded the late planting date $\left(10^{\text {th }}\right.$ June $)$ for all yield and yield components traits in both seasons. While, the late planting date in $10^{\text {th }}$ June exceeded the early planting dates in May for Si contents and oil percentage in both seasons. Spraying high level of silicon on soybean plants led to a significant increase in 100-seed weight and seed yield/fed, while spraying $100 \mathrm{mg} / \mathrm{L}$ of silicon gave the highest percentage of oil in seeds in both seasons. The increase in the level of silicon from 100 to 200 and $300 \mathrm{mg} / \mathrm{L}$ resulted in a significant increase in the number of pods / plant in both planting dates $\left(1^{\text {st }}\right.$ and $20^{\text {th }}$ May), while the highest level of silicon $300 \mathrm{mg} / \mathrm{L}$ led to a significant increase in the 100 -seed weight in the $1^{\text {st }}$ and $2^{\text {nd }}$ planting dates $\left(1^{\text {st }}\right.$ May and $20^{\text {th }}$ May) in both seasons. The results showed that the highest seed yield/fed was obtained by spraying $300 \mathrm{mg} / \mathrm{L}$ of silicon at the $1^{\text {st }}$ planting date $\left(1^{\text {st }}\right.$ May). Finally, the highest oil percentage was presented in the 3rd planting date was shown on $10^{\text {th }}$ June by spraying $200 \mathrm{mg} / \mathrm{L}$ of silicon followed by spraying $200 \mathrm{mg} / \mathrm{L}$ at the first planting date in both seasons.
\end{abstract}

Keywords: Soybean, Silicon (Si), planting date, heat stress, migrators, productivity.

\section{INTRODUCTION}

Soybean (Glycine max L.) is widely grown for its edible bean, which has numerous uses. Soybean is the most important protein source for animals feeding and human food. Among the legumes, soybean is valued for its high (38-45\%) protein content, also soybean seed contains 18-19\% oil (Livestock's long shadow, 2016). Total cultivated area of soybean in the world in 2017 was about 123.5 million ha produced about 352.64 million tons, while in Egypt, the cultivated area was about 15000 ha produced approximately 45000 ton from dry seeds (FAO STAT, 2018).

Heat stress and drought are the most important abiotic stresses that limit the growth and yield of soybean which are mainly due to climate change. In general, Crop production affected seriously by climate factors, such as water and temperature. The change in climatic factors may lead to unfavorable effects on crop growth and physiological processes in the plants (Vadez et al., 2012). The ever-rising global temperatures, consequence of higher greenhouse gas anthropogenic emissions, have a bad effect on the global agricultural sector. Limited plant growth and reduced yields due to heat stress, paired with limited water availability, is already forcing farmers to adapt their production systems to 
the new challenging environmental conditions (HLPE, 2012). Higher temperatures, coupled with limited water availability, will challenge the agricultural production in tropical, sub-tropical and Mediterranean regions (Kurukulasuriya and Rosenthal, 2013). Heat stress (HS) caused by elevated ambient temperatures is usually associated with drought stress, and represents a substantial problem in many agricultural areas around the world due to its negative impact on plant growth and economical yield (Branca et al., 2013). The optimum rate of seed growing temperatures for most crops is located between 10 and $30^{\circ} \mathrm{C}$, and can decrease significantly outside this threshold. Establishment of upper and lower temperature thresholds results imperative for crop production in order to avoid cold or heat injuries to the crop (Morales et al., 2003). Heat stress can cause alterations on plant physiological such shoots and roots, reduced number of flowers or potential flower abortion, and fruit or pod damage. In addition to heat stress results detrimental for the growth and development of the plant, and can substantially affect the economical yield and food production (Howarth, 2005).

In legume crops, heat stress is particularly damaging since it affects the symbiotic $\mathrm{N}_{2}$ fixation with soil bacteria, causing inadequate nitrogen nutrition, hence unstable and low yields. Increase temperatures $5^{\circ} \mathrm{C}$ above the optimal temperature during seed filling might have an influence on $\mathrm{N}$ - partitioning reducing the rate of nitrogen remobilization from vegetative parts to grow seeds in seed legumes (Munier-Jolain, and Larmure 2007). Also, Pirdashti, and Yaghoubian (2014) reported that temperature plays important role in plant growth and development. Exposure of plants to extreme temperatures damages the living tissue, causing alterations in cell-membrane stability, interruption of cell division and elongation, limiting plant productivity. Often to avoid the effect of heat stress and drought in field crops, there is a set of procedures to be followed, including the cultivation of the tolerant cultivar. It is also necessary to change planting dates of these crops to avoid the bad effects of stress at the critical stages of crop age, and of these measures concern the nutritional status of the crop, such as adding or spraying drought shields such as silicon.

As for planting date Egli and Cornelius (2009) indicated that planting date is an important factor affecting soybean seed yield and seed quality. Choosing the planting date is an effective way to improve soybean growth and development and to enhance the seed yield and seed storability. The optimum date of planting, enables favorable environmental conditions for growth and seed yield. Among the agronomic practices, planting date has remarkable effect on soybean seed yield. However, the effect of planting date on soybean seed yield depends on genetic and environmental conditions. Different planting dates subject the soybean plant to different environmental conditions which in turn affect the growth and development of vegetative and reproductive components of yield and physiological processes. Besides this, soybean seed is most perishable and its viability and vigor are highly affected by the weather conditions in the field. Also, Karaaslan et al. (2012) reported that plant height, pod number, 1000 seeds weight and seed yield of soybean significantly influenced by the different planting dates. Planting date of soybean is one of important environmental factor determining soybean yield and its components. 
As for the effect of silicon in plant protection against the risk of stress, there are many studies that have emphasized the importance of silicon in the increase of growth and production under heat stress and drought. plays an important role in protecting plants from abiotic and biotic stresses. For instance, silicon is effective in alleviating abiotic stresses, including salinity, drought and temperature (Liang et al., 2008). Foliar application of silicon enhanced pollination, dry biomass, and final yield (Korndorfer and Lepsch, 2001). It has better on growth and development and physiological function of soybean (La et al., 2004). Silicon silicate applied to the soil mitigated the adverse dray mass reduction effects of drought in 6 of 12 sunflower cultivars. (Gunes et al. 2008). Silicon was more effective in alleviating salinity their drought stress in soybean. They found that the adverse e effects of NaCL and PEG on plant growth were alleviated by adding $100 \mathrm{mg} / \mathrm{L}$ and $200 \mathrm{mg} / \mathrm{L} \mathrm{Si}$ to salt and drought stressed treatments in terms of shoot, length shoot mass, root mass and chlorophyll content (Amayun et al., 2010). The addition of 2-5 mM Si to soybean plants was beneficial in hydroponically grown plants asset significantly improves growth attributes, and effectively mitigate the adverse effects of NACL induced salts tress (Lee et al. 2010).

The aims of this study were to:

1- Study the effect of planting date on yield and yield components of soybean to determine the best planting date, which will increase seed production and quality and avoid exposure of the crop to heat and drought stress at critical stages of their life cycle.

2- Study the effect of spraying different concentrations of silicon compared to control on yield and yield components of soybean to determine the best concentration to increase the production and quality of seeds, also avoid the exposure of the crop to heat and drought stress at critical stages of age.

3- Study the interaction effect between silicon concentrations and planting dates on yield and its components of soybean to determine the best concentration and the best planting date, which will increase the production and quality of seeds and avoid exposure of the crop to heat and drought stress at critical stages of soybean plants.

\section{MATERIALS AND METHODS}

Two field experiments were conducted out at the experimental Farm of Agricultural Research Station (A.R.C.), Itay El-Baroud, EL-Behiera Governorate, Egypt, during the two summer seasons of 2017 and 2018 to study the effect of foliar application of silicon at the rate of $100,200,300 \mathrm{mg} / \mathrm{L}$ and control (water spray) to reduce the heat stress effect in the commercial soybean cultivar Giza 111 under three planting dates $1^{\text {st }}$ May, $20^{\text {th }}$ May and $10^{\text {th }}$ June using yield measurement to determine the optimal planting date and the best silicon concentration could be used to maximized seed yield and seed quality under heat stress conditions.

Physical and chemical properties of experimental soil are presented in Table 1 which according method described by Page et al. (1982). 
Table (1). Physiochemical properties of experimental soil in both seasons

\begin{tabular}{|c|c|c|}
\hline \multirow{2}{*}{ Properties } & \multicolumn{2}{|c|}{ Seasons } \\
\hline & 2017 & 2018 \\
\hline \multicolumn{3}{|c|}{ Particle size distribution (\%) } \\
\hline Clay & 60.41 & 59.61 \\
\hline Slit & 32.5 & 31.8 \\
\hline Sand & 7.09 & 8.59 \\
\hline Textural class & \multicolumn{2}{|c|}{ Clay } \\
\hline $\mathrm{CaCO}_{3}$ & 3.15 & 2.45 \\
\hline OM (\%) & 0.68 & 0.54 \\
\hline $\mathrm{pH}^{\mathrm{H}}$ & 7.70 & 7.75 \\
\hline $\mathrm{EC}(\mathrm{dS} / \mathrm{m})$ & 1.93 & 1.88 \\
\hline \multicolumn{3}{|c|}{ Soluble cations (meq/L) } \\
\hline $\mathrm{Ca}++$ & 6.12 & 5.10 \\
\hline $\mathrm{Mg}++$ & 3.54 & 2.61 \\
\hline $\mathrm{K}+$ & 1.56 & 1.64 \\
\hline $\mathrm{Na}+$ & 8.17 & 6.89 \\
\hline \multicolumn{3}{|c|}{ Soluble Anions (meq/L) } \\
\hline $\mathrm{Cl}-$ & 10.11 & 8.42 \\
\hline $\mathrm{HCO}_{3}^{--}$ & 0.85 & 0.70 \\
\hline $\mathrm{SO}_{4}^{--}$ & 8.43 & 7.02 \\
\hline \multicolumn{3}{|c|}{ Available nutrient (mg/kg) } \\
\hline $\mathrm{K}+$ & 74.11 & 68.34 \\
\hline$P$ & 2.66 & 2.34 \\
\hline $\mathrm{N}$ & 41.78 & 40.09 \\
\hline
\end{tabular}

This experiment was laid out in split plot design with three replications, the three planting dates were allocated at main plots and the silicon concentration treatments were distributed at random in a sub-plot. In both seasons of 2017 and 2018 soybean seeds were sown in $1^{\text {st }}$ May, $20^{\text {th }}$ May and $10^{\text {th }}$ June. Each sub plot included 5 ridges. Each ridge was 3 meters long and $70 \mathrm{~cm}$ apart. Seeds were sown on sides of the ridge at $20 \mathrm{~cm}$ hill apart with two seed per hill. The wet planting method called (Herati) was used and all the other cultural practices were followed as Ministry of Agriculture and Land Reclamation recommendations. The commercial silicon from El Jomhoureya Company Cairo- Egypt were prepared in concentrations of 100,200 and $300 \mathrm{mg} / \mathrm{L}$ and sprayed three times during the growing season after 45, 60 and 75 day from seed planting at the same times control was sprayed with tab water only. The minimum and maximum temperatures in addition to relative humidity during the two growing seasons were presented in Tabl (2).

Table (2). Maximum, minimum temperature and relative humidity at Itay EL-Baroud Agricultural Research Station, EL-Behiera Governorate, Egypt in 2017 and 2018 seasons

\begin{tabular}{ccccccc}
\hline \multirow{2}{*}{ Week } & \multicolumn{3}{c}{ Temperature $\left(\mathbf{C}^{\mathbf{0}}\right)$} & \multirow{2}{*}{ Relative humidity (\%) } \\
\cline { 2 - 5 } & \multicolumn{2}{c}{$\mathbf{2 0 1 7}$} & \multicolumn{2}{c}{$\mathbf{2 0 1 8}$} & & $\mathbf{2 0 1 7}$ \\
\cline { 2 - 6 } & Min. & Max. & Min. & Max. & $\mathbf{2 0 1 8}$ \\
\hline May & 17.1 & 38.0 & 22.0 & 40.9 & 65.0 & 62.1 \\
June & 20.5 & 40.2 & 20.3 & $40 . .8$ & 73.0 & 71.8 \\
July & 19.1 & 37.3 & 20.5 & 35.9 & 74.8 & 79.0 \\
August & 17.4 & 36.7 & 20.0 & 35.4 & 72.2 & 77.3 \\
September & 17.0 & 35.7 & 19.0 & 32.4 & 68.5 & 73.2 \\
\hline
\end{tabular}


At harvest time, 120 days from planting yield and yield components were determined i.e. number of pods /plants, 1000- seed weight (g), and seed yield /fed. Silicon determination: Plant samples were collected in labeled bages, washed with distilled water to remove surface contaminants. The samples were air dried, and subjected in oven at $500^{\circ} \mathrm{C}$ until ashing. An aliquot of dried samples was digested by using sulphric and perchloric acids according to the method described by (AOAC, 1995). The prepared sample was examined for silicon content on Inductive Coupled Plasma (ICP)- Optical Emission Spectroscopy (ICP-OES) (model Ultima 2JY Plasma) according to EPA (1991).

Oil \% was determined using soxcelt apparatus using n-hexan, according to AOAC (1995). All collected data were subjected to analysis of variance according to Gomez and Gomez (1984). All statistical analysis was performed using analysis of variance technique by means of CoStat (2005) computer soft were package.

\section{RESULTS AND DISCUSSION}

\section{1- Effect of planting dates on seed yield and yield components traits of soybean CV. Giza111 in seasons of 2017 and 2018.}

The presented results in Table (3) showed that mean squares due to planting dates of soybean cv. Giza111 during the two summer seasons of 2017 and 2018 were highly significant and /or significant for yield and yield components traits and these may a clear evident that all yield parameters of the soybean cv. Giza 111 in this study will differ in their mean from planting date to another.

The presented results showed that planting soybean during May $1^{\text {st }}$ and $20^{\text {th }}$ exceeded the late planting date $\left(10^{\text {th }}\right.$ June) for all yield and yield components traits in both seasons. While, the late planting date in $10^{\text {th }}$ June exceeded the early planting dates in May for Si contents and oil percentage in both seasons. Also, the results in Table (3) indicated that soybean cv. Giza 111 under the $1^{\text {st }}$ planting date $\left(1^{\text {st }}\right.$ May) showed excellent mean values for number of pods/plant in both seasons (36.52 and 35.95), 100-seed weight in the $2^{\text {nd }}$ season with average of $16.21 \mathrm{~g}$ and seed yield/fed $(1275.9$ and $1328.5 \mathrm{~kg} / \mathrm{fed})$ in both seasons respectively. In the same line, the $2^{\text {nd }}$ planting date in $20^{\text {th }}$ May showed desirable means for number of pods/plant in in the $1^{\text {st }}$ season with average of 34.50 , 100- seed weight (16.32 and $16.19 \mathrm{~g}$ ) and seed yield/fed $(1248.57$ and $1315.43 \mathrm{~kg} / \mathrm{fed})$ in both seasons respectively. Finally, the $3^{\text {rd }}$ planting date in $10^{\text {th }}$ June showed the highest mean values for Si content in dry seed (71.09 and 72.06 (mg/100g d.wt.)) and oil percentage (20.63 and 20.38 (\%) in in both seasons of 2017 and 2018, respectively.

These finding indicated that the number of pods/plant, 100- seed weight and seed yield/fed were obtained when soybean planted during May $\left(1^{\text {st }}\right.$ and $20^{\text {th }}$ May) these traits sharply decreased in the late planting date $\left(10^{\text {th }}\right.$ June). While, planting soybean 20 days before or after the optimal planting date in $20^{\text {th }}$ May led to increased oil \%. many results were in agree with our finding such as, 
Bastidas et al. (2008) observed a curved response of soybean plant height to delayed planting because earlier planting led to more nodes. Also, delayed planting date has little or no effect on soybean seed mass. Delayed planting after May decreased soybean seed yield. Perez (2007) demonstrated that delayed planting reduced yield and yield components of soybean. Also reported that delayed planting from May to July reduced seed yield. Also, Nishioka and Okumura (2008) indicated that the soybean number of pods and yield decreased with delay in the planting time. However, Sadeghi and Niyaki (2013) stated that the soybean cultivars with early planting produced higher yield and quality as compared to the late planting date. Earlier planting provided higher yields than the delayed planting in soybean. Also, Yansheng et al. (2014) indicated that the planting of soybean after 15 May increased seed protein content by $4.10 \%$ to $7.50 \%$ and reduced oil content by $2.40 \%$ to $26.30 \%$ for different cultivars. On the other side, Morsy et al. (2016) showed that delayed planting date from May 3 to June 4 significantly decreased number of pods/plant along with reducing of 100 -seeds weight and seed yield ( $\mathrm{kg} / \mathrm{fed}$ ). Also, Naoki et al. (2016) reported that when planting soybean in early dates recoeded an increase in yield. On the other hand, Yohei et al. (2018) found that yield was significantly reduced following late sparse planting. While, in the contrast of our finding Madhavi et al. (2000) reported that soybean sown on $1^{\text {st }}$ July had the highest number of pods/plant (85.9) and seed yield/plant $(6.49 \mathrm{~g})$. Soybean planted in the northeastern United States in mid-June had fewer pods/plant, and lower seed yield compared to mid-May planting.

The results of the analysis of variance due to the effect of spraying with the different concentrations of silicon on the Giza 111 soybean (Table 3 ) were highly significant for all yield and yield component traits in both seasons except for oil percentage in the $2^{\text {nd }}$ sowing date. This is due to improving the silicon for growth and metabolism will ultimately increase seed yield.

The results shown in Table (3) showed that spraying high concentrations of silicon on soybean plants led to a significant increase in yield characteristics and components. The spraying of $300 \mathrm{mg} / \mathrm{L}$ of silicon resulted in the highest number of pods in both seasons (40.24 and 40.37), 100-seed weight (16.75 and $16.84 \mathrm{~g})$ and seed yield/fed (1496.46 and $14329.82 \mathrm{~kg}$ ) followed by The spraying with $200 \mathrm{mg} / \mathrm{L}$ of silicon and their superior the concentration of $100 \mathrm{mg} / \mathrm{L}$ and the control in both seasons respectively. On the other hand, spraying at the level of $100 \mathrm{mg} / \mathrm{L}$ of silicon gave the highest percentage of oil in seeds with an average of 20.82 and $20.65 \%$ in both seasons respectively, followed by the level of $200 \mathrm{mg} / \mathrm{L}$ and $300 \mathrm{mg} / \mathrm{L}$ respectively, confirming the superiority of spraying on silicon treatment control.

These results are in harmony with reported by Shen et al. (2010) who revealed that the addition of $1.7 \mathrm{mM}$ Si significantly increased soybean yield and dry mass by $26 \%$ when subjected to $-0.5 \mathrm{MPa}$ of PEG stress. Also, Gholami and Falah (2013) reported an increase in number of tillers, dry leaves weight, 100-seed weight, and yield of two rice varieties grown in Iran upon silicon fertilization to the soil. Also, Tahir et al (2013) found that silicon application significantly enhanced yield, its components protein content and oil 
contents. Meena et al. (2014) suggested that depletion of plant available silicon from soil is the limiting factor contributing to declining yield. Also, Vasanthi et al. (2014) stated that silicon nutrition reverses the succulence induced by high nitrogen and enhance crop growth and yield.

Table (3). Seed yield and its components of soybean cv. Giza111 as affected by planting dates and foliar application of silicon in both seasons

\begin{tabular}{|c|c|c|c|c|c|c|c|c|c|c|}
\hline \multirow[t]{2}{*}{ Treatments } & \multicolumn{2}{|c|}{$\begin{array}{c}\text { No. of } \\
\text { pods/plant }\end{array}$} & \multicolumn{2}{|c|}{$\begin{array}{l}\text { 100-seed } \\
\text { weight }(\mathrm{g})\end{array}$} & \multicolumn{2}{|c|}{$\begin{array}{l}\text { Seed yield/fed. } \\
\text { (kg) }\end{array}$} & \multicolumn{2}{|c|}{$\begin{array}{c}\mathrm{Si} \\
(\mathrm{mg} / \mathrm{kg})\end{array}$} & \multicolumn{2}{|c|}{ Oil \% } \\
\hline & 2017 & 2018 & 2017 & 2018 & 2017 & 2018 & 2017 & 2018 & 2017 & 2018 \\
\hline \multicolumn{11}{|c|}{ Planting dates } \\
\hline $1^{\text {st }}$ May & $36.52^{\mathrm{a}}$ & $35.95^{\mathrm{a}}$ & $15.84^{\mathrm{b}}$ & $16.21^{\mathrm{a}}$ & $1275.91^{\mathrm{a}}$ & $1328.50^{\mathrm{a}}$ & $18.66^{\mathrm{C}}$ & $19.22^{\mathrm{C}}$ & $21.01^{\mathrm{a}}$ & $20.95^{\mathrm{a}}$ \\
\hline $20^{\text {th }}$ May & $34.50^{\mathrm{a}}$ & $34.38^{\mathrm{b}}$ & $16.32^{\mathrm{a}}$ & $16.19^{\mathrm{a}}$ & $1248.57^{\mathrm{a}}$ & $1315.43^{\mathrm{a}}$ & $49.75^{\mathrm{b}}$ & $53.03^{\mathrm{b}}$ & $19.73^{\mathrm{b}}$ & $19.43^{\mathrm{b}}$ \\
\hline $10^{\text {th }}$ June & $28.90^{\mathrm{b}}$ & $29.92^{\mathrm{c}}$ & $15.12^{\mathrm{c}}$ & $15.32^{\mathrm{b}}$ & $985.48^{\mathrm{b}}$ & $889.84^{\mathrm{b}}$ & $71.09^{\mathrm{a}}$ & $72.06^{\mathrm{a}}$ & $20.63^{\mathrm{a}}$ & $20.38^{\mathrm{a}}$ \\
\hline LSD at 0.05 & 2.31 & 1.16 & 0.10 & 0.22 & 32.22 & 43.35 & 0.91 & 1.16 & 0.48 & 0.88 \\
\hline \multicolumn{11}{|c|}{ Foliar application of silicon (mg/L) } \\
\hline Control (water) & $24.41^{\mathrm{d}}$ & $25.20^{\mathrm{d}}$ & $14.89^{\mathrm{d}}$ & $15.04^{\mathrm{d}}$ & $764.10^{\mathrm{d}}$ & $827.96^{\mathrm{C}}$ & $23.03^{\mathrm{d}}$ & $23.72^{\mathrm{d}}$ & $20.07^{\mathrm{b}}$ & $19.92^{\mathrm{b}}$ \\
\hline 200 & $36.36^{\mathrm{b}}$ & $37.35^{\mathrm{b}}$ & $16.16^{\mathrm{b}}$ & $16.41^{\mathrm{b}}$ & $1369.30^{\mathrm{b}}$ & $1402.10^{\mathrm{a}}$ & $53.66^{\mathrm{b}}$ & $55.84^{\mathrm{b}}$ & $20.78^{\mathrm{a}}$ & $20.48^{\mathrm{ab}}$ \\
\hline 300 & $40.24^{\mathrm{a}}$ & $40.37^{\mathrm{a}}$ & $16.75^{\mathrm{a}}$ & $16.84^{\mathrm{a}}$ & $1496.46^{a}$ & $1429.82^{\mathrm{a}}$ & $63.50^{\mathrm{a}}$ & $66.45^{\mathrm{a}}$ & $20.14^{\mathrm{b}}$ & $19.97^{\mathrm{ab}}$ \\
\hline 100 & $32.22^{\mathrm{c}}$ & $30.74^{\mathrm{c}}$ & $15.23^{\mathrm{c}}$ & $15.35^{\mathrm{C}}$ & $1050.08^{c}$ & $1051.81^{\mathrm{b}}$ & $45.81^{\mathrm{C}}$ & $46.40^{\mathrm{C}}$ & $20.82^{a}$ & $20.65^{\mathrm{a}}$ \\
\hline LSD at 0.05 & 1.75 & 3.26 & 0.14 & 0.16 & 34.30 & 33.44 & 1.08 & 1.00 & 0.62 & 0.72 \\
\hline
\end{tabular}

\section{Effect of the interaction between Planting dates and Silicon spraying treatments on seed yield, and yield component traits and seed chemical compositions of soybean cv. Giza111 during seasons of 2017 and 2018.}

The results presented in Table (4) showed that the increase in the level of silicon from 100 to 200 and $300 \mathrm{mg} / \mathrm{L}$ resulted in a significant increase in the number of pods/ plants in the $1^{\text {st }}$ and $2^{\text {nd }}$ planting dates ( $1^{\text {st }}$ May and $20^{\text {th }}$ May) in both seasons. The largest number of pods/plants was obtained by spraying $300 \mathrm{mg} / \mathrm{L}$ of silicon at the first planting date (43.10 and 44.44) followed by 200 $\mathrm{mg} / \mathrm{L}$ of silicon at the first planting date (42.52 and 41.46$)$ and $300 \mathrm{mg} / \mathrm{L}$ of silicon at the second planting date (40.50 and 41.00) in both seasons respectively. The highest weight of 100 -seeds was obtained by spraying 300 $\mathrm{mg} / \mathrm{L}$ of silicon at the first planting date (16.80 and 17.19) and by $300 \mathrm{mg} / \mathrm{L}$ of silicon at the second planting date (17.34 and 17.03) and then $200 \mathrm{mg} / \mathrm{L}$ of silicon at the first and the second planting date in both seasons respectively.

Also, the results in the same Table showed that the highest seed yield /fed. was obtained by spraying $300 \mathrm{mg} / \mathrm{L}$ of silicon at $1^{\text {st }}$ May with an average of 1612.54 and 1696.40 in both seasons respectively. Followed by spraying 300 $\mathrm{mg} / \mathrm{L}$ of silicon at the $2^{\text {nd }}$ planting date $\left(20^{\text {th }}\right.$ May) with an average of 1593.43 and $1568.30 \mathrm{~kg}$ in the $1^{\text {st }}$ planting date in first and second seasons respectively, and spraying $200 \mathrm{mg} / \mathrm{L}$ of silicon in the first planting date in the 2017 season (1575.01) and spraying $200 \mathrm{mg} / \mathrm{L}$ of silicon In the second planting date in the 2018 season with an average of $1574.83 \mathrm{~kg}$. The results showed that spraying of silicon at any of the three levels increased the seed yield/fed at all planting dates in both seasons compared to control. The highest content of the silicon in 
the seeds was obtained in the third planting date of $10^{\text {th }}$ June by spraying 300 $\mathrm{mg} / \mathrm{L}$ of silicon (90.87 and 92.30) followed by spraying $200 \mathrm{mg} / \mathrm{L}$ at the same planting date (87.27 and 89.59) and spraying $100 \mathrm{mg} / \mathrm{L}$ Silicon at the $3^{\text {rd }}$ planting date $10^{\text {th }}$ June with an average of 83.27 and 82.72 in the 2017 and 2018 seasons, respectively.

The results presented in Table (4) showed significant effect of silicon spraying on the percentage of oil in seeds compared with control at all planting dates in both seasons. $200 \mathrm{mg} / \mathrm{L}$ of silicon was sprayed on the third date and the first led to an increase in the oil percentage in the seeds. The highest percentage of oil in the third planting date was shown on $10^{\text {th }}$ June by spraying $200 \mathrm{mg} / \mathrm{L}$ of silicon (21.42 and $21.15 \%$ ) followed by spraying $200 \mathrm{mg} / \mathrm{L}$ at the first planting date (21.00 and 20.98\%) in 2017 and 2018 respectively.

Table (4). Interaction effect between planting dates and foliar application of silicon on seed yield and yield components traits of soybean cv. Giza111 in both seasons

\begin{tabular}{|c|c|c|c|c|c|c|c|c|c|c|c|}
\hline \multirow{2}{*}{$\begin{array}{c}\text { Planting } \\
\text { dates }\end{array}$} & \multirow{2}{*}{$\begin{array}{l}\text { Silicon } \\
\text { conc. } \\
\text { (mg/L) }\end{array}$} & \multicolumn{2}{|c|}{$\begin{array}{c}\text { No. of } \\
\text { pods/plant }\end{array}$} & \multicolumn{2}{|c|}{$\begin{array}{l}100 \text { - seed } \\
\text { weight }(\mathrm{g})\end{array}$} & \multicolumn{2}{|c|}{$\begin{array}{l}\text { Seed yield } \\
\text { /fed (kg) }\end{array}$} & \multicolumn{2}{|c|}{$\begin{array}{c}\mathrm{Si} \\
(\mathrm{mg} / \mathrm{kg})\end{array}$} & \multicolumn{2}{|c|}{ Oil \% } \\
\hline & & 2017 & 2018 & 2017 & 2018 & 2017 & 2018 & 2017 & 2018 & 2017 & 2018 \\
\hline \multirow{4}{*}{$1^{\text {st }}$ May } & 100 & $35.07^{c}$ & $32.19^{\mathrm{de}}$ & $15.42^{\mathrm{e}}$ & $15.44^{f}$ & $1054.48^{\mathrm{e}}$ & $1177.03^{c}$ & $11.10^{k}$ & $11.43^{k}$ & $21.65^{a}$ & $21.73^{a}$ \\
\hline & 200 & $42.52^{\mathrm{ab}}$ & $41.46^{\mathrm{ab}}$ & $15.96^{c}$ & $16.89^{b}$ & $1575.01^{a}$ & $1561.88^{b}$ & $19.10^{\mathrm{j}}$ & $19.67^{j}$ & $20.82^{\mathrm{abc}}$ & $20.55^{\mathrm{abcd}}$ \\
\hline & 300 & $43.10^{a}$ & $44.44^{a}$ & $16.80^{b}$ & $17.19^{a}$ & $1612.54^{a}$ & $1696.40^{a}$ & $34.10^{h}$ & $35.12^{h}$ & $21.00^{a b}$ & $20.98^{a b}$ \\
\hline & Control & $25.38^{\mathrm{e}}$ & $25.71^{g h}$ & $15.17^{f}$ & $15.32^{f}$ & $861.59^{f}$ & $878.71^{\mathrm{e}}$ & $10.34^{k}$ & $10.65^{k}$ & $20.55^{\text {bcd }}$ & $20.55^{\mathrm{abcd}}$ \\
\hline \multirow{4}{*}{$20^{\text {th }}$ May } & 100 & $35.50^{c}$ & $31.00^{\text {ef }}$ & $15.70^{d}$ & $15.73^{\mathrm{de}}$ & $1234.68^{c}$ & $1214.51^{c}$ & $43.07^{f}$ & $45.07^{f}$ & $19.93^{\text {cdef }}$ & $19.65^{\text {cde }}$ \\
\hline & 200 & $36.00^{c}$ & $38.50^{\mathrm{bc}}$ & $16.90^{b}$ & $16.53^{c}$ & $1356.08^{b}$ & $1574.83^{b}$ & $54.60^{\mathrm{e}}$ & $58.27^{\mathrm{e}}$ & $20.12^{\text {bcde }}$ & $19.73^{\text {cde }}$ \\
\hline & 300 & $40.50^{b}$ & $41.00^{\mathrm{ab}}$ & $17.34^{a}$ & $17.03^{\mathrm{ab}}$ & $1593.43^{a}$ & $1568.30^{b}$ & $65.53^{d}$ & $71.91^{d}$ & $19.60^{\text {ef }}$ & $19.35^{\mathrm{de}}$ \\
\hline & Control & $26.00^{\mathrm{e}}$ & $27.00^{\mathrm{fgh}}$ & $15.33^{\mathrm{ef}}$ & $15.47^{\mathrm{ef}}$ & $810.08^{9}$ & $904.06^{\mathrm{e}}$ & $35.80^{g}$ & $36.87^{9}$ & $19.25^{f}$ & $18.98^{\mathrm{e}}$ \\
\hline \multirow{4}{*}{$10^{\text {th }}$ June } & 100 & $26.08^{\mathrm{e}}$ & $29.02^{\mathrm{fg}}$ & $14.56^{\mathrm{g}}$ & $14.88^{\mathrm{g}}$ & $861.07^{f}$ & $763.88^{f}$ & $83.27^{c}$ & $82.72^{c}$ & $20.87^{\mathrm{ab}}$ & $20.57^{\mathrm{abc}}$ \\
\hline & 200 & $30.56^{d}$ & $32.09^{\mathrm{de}}$ & $15.63^{d}$ & $15.78^{d}$ & $1176.81^{d}$ & $1069.60^{d}$ & $87.27^{b}$ & $89.59^{b}$ & $21.42^{a}$ & $21.15^{\mathrm{ab}}$ \\
\hline & 300 & $37.11^{\mathrm{c}}$ & $35.67^{\text {cd }}$ & $16.10^{c}$ & $16.30^{c}$ & $1283.41^{c}$ & $1024.75^{d}$ & $90.87^{a}$ & $92.30^{\mathrm{a}}$ & $19.83^{\text {def }}$ & $19.57^{\text {cde }}$ \\
\hline & Control & $21.85^{f}$ & $22.88^{\mathrm{h}}$ & $14.18^{\mathrm{h}}$ & $14.31^{\mathrm{h}}$ & $620.63^{h}$ & $701.120^{g}$ & $22.95^{\mathrm{k}}$ & $23.64^{i}$ & $20.42^{\text {bcde }}$ & $20.22^{\text {bcd }}$ \\
\hline \multicolumn{2}{|c|}{ LSD at $5 \%$} & 2.50 & 4.66 & 0.20 & 0.25 & 49.04 & 47.80 & 1.54 & 1.43 & 0.88 & 1.03 \\
\hline
\end{tabular}

- Mean values in the same column marked with the same letters are not significantly different at 0.05 level of probability.

\section{CONCLUSION}

As a result of these two growing seasons field's study, it was concluded that yield, its components of soybean crop increased with planting date soybean $\mathrm{cv}$. Giza 111 at the $1^{\text {st }}$ of May with foliar application of silicon (Si) at the rate of $300 \mathrm{mg} / \mathrm{L}$ three times under study conditions at Itay El-Baroud, EL-Behiera Governorate, Egypt. 


\section{REFERENCES}

Amayun, H.M., E.Y. Sohn, S.A. Khn, Z.K. Shinwai, A.L. Khan and I.J. Lee.(2010). Silicon alleviates the adverse effects of salinity and drought stress on growth and endogenous plant growth hormones of soybean(Glycine max L.).Pak. J. BOT., 42:1713-1722.

AOAC (1995). Method of Analysis Association of Official Agriculture Chemists. $16^{\text {th }}$ Ed. Washington, D. C, USA.

Bastidas, A.M. T.D. Setryono, A. Dobermann, K.G. Cassman, R.W. Elmore, G.L. Graef and J.E. Specht (2008). Soybean planting date: The vegetative, reproductive, and agronomic impacts. Crop Sci. 48:727-740.

Branca, G. L. Lipper, N. McCarthy and M.C. Jolejole (2013). Food security, climate change and sustainable management. A review. Agron. Sustain. Dev., 33,635 -650.

CoStat-Cohort Software (2005). CoStat User Manual, version 3 Cohort Tucson, Arizona, USA.

Egli, D.B. and P.L. Cornelius (2009). A regional analysis of the response of soybean yield to planting date. Agronomy J. 101: 330-335.

EPA. (1991). Methods for determination of metals in environmental samples. Office of research and development Washington DC. PP. 23-29 and 83122.

FAOSTAT (2018). Soybean, cultivated area and production. Food and Agriculture Organization of the United Nation, 2018.

Gholami, Y. and A. Falah (2013). Effects of two different sources of silicon on dry matter production, yield, and yield components of rice, Tarom Hashemi variety and 843 lines. International J. Agri. and Crop Sci., 5, 227-231.

Gomez, K.A and A.A. Gomez (1984). Statistical procedures in agricultural research. $2^{\text {nd }}$ edition. Wiley, NewYork.

Gunes,A.,D J. Pilbeam,A. Inal, and S. Coban.( 2008).Influence of silicon on sun flower cultivars under drought stress, I, growth, antioxidant mechanisms, and lipid peroxidase.Comm. Soil Analysis .14(3): 18851903.

HLPE. (2012). Food Security and Climate Change. High Level Panel of Food Security and Nutrition of the Committee on World Food Security.

Karaaslan, D. M. Hakan, R. Ekinci and E. Boydak (2012). The impact of different seeding dates on seed yield of soybean. J. of Animal and Plant Sci., 22(1):175-182.

Korndorfer, G.H. and I. Lepsch (2001). Effect of silicon on plant growth and crop yield. In: Silicon in Agriculture: Studies in Plant Sci., 8:115-131.

Kurukulasuriya, P. and S. Rosenthal (2013). Climate change and agriculture: A review of impacts and adaptations. Retrieved from Washington, D.C.:https://openknowledge.worldbank.org/handle/10986/16616 License: CC BY 3.0 IGO.

La, Q. C. Ma, H. Li, Y. Xiao and X. Liu (2004). Effect of available silicon on growth, development and physiological functions of soybean. Ying youg sheng Taixue Bao., 15(1):73-76. 
Lee, S.K., E.Y. Sohn, M. Hamayun, J. Y. Yoon and I. G. Lee (2010). Effect of silicon on growth and salinity stress of soybean plant grown under hydroponic system Agroforest Sagest, 80:333- 340.

Liang. Y.C., J. Zhu and Z.J. Li (2008). Role of silicon in enhancing resistance to freezing stress in two contrasting winter wheat cultivars. Environmental and Experimental Botany 64: 286 - 294.

Livestock's long shadow (2016). Environmental issues and options. www.fao.org. Retrieved 2016-01-15.

Madhavi, P. N.V. Ramaiah, V. Satyanarayana and B. Vijaykumar (2000). Effect of planting dates and fertilizer levels on yield and quality of soybean under Telangana region of Andhra Pradesh. The Journal of Research ANGRAU. 29(4):92-94.

Meena, V. D. M. L. Dotaniya, V, Coumar, S. Kundu and A. S. Rao, (2014). A case of silicon fertilization to improve the crop yields in tropical soil. Proc. Natl. Acad. Sci., India sec. B:Bio.Sci., 84(3):505-512

Morales, D. P. Rodríguez, J. Dell'amico, J. Nicolás, E. Torrecillas, A. Sánchez and M. J. Blanco (2003). High-temperature preconditioning and thermal shock imposition affects water relations, gas exchange and root hydraulic conductivity in tomato. Biologia. Plantarum, 47(2):203-208.

Morsy, A. R. Alaa, M. E.A. Shahein and T. A. Selim (2016). Stability of seed yield and seed quality of some soybean genotypes under different planting dates. Alex. J. Agric. Sci. 61(6): 635-648.

Munier-Jolain, P.V.N.G. and A. Larmure (2007). High temperatures applied during seed filling of pea (Pisum sativum L.) affect seed growth and nitrogen partitioning within plant. Paper presented at the $6^{\text {th }}$ European Conference on Seed Legumes, Lisbon, Portugal. Plant Resources for Tropical Africa 1. Cereals and pulses. (2006). M. Brink \& G. Belay (Eds.), PROTA Foundation (pp. 298).

Naoki, M. K. Fukami and S. Tsuchiya (2016). Effects of early planting and cultivars on the yield and agronomic traits of soybean grown in southwestern Japan. Plant Production Sci., 19 (3): 370-380.

Nishioka, H. and T. Okumura (2008). Influence of planting time and nitrogen topdressing at the flowering stage on the yield and pod character of green soybean (Glycine max L.) Merril). Plant Production Sci. 11(4): 507513.

Page, A.L., R.H. Miller and D.R. Keeney (1982). Methods of Chemical Analysis. Part 2: Chemical and Microbiological Properties (2nd Ed.). American Society of Agronomy, Inc. and Sci. Soc. of America, Inc. Publi., Madison, Wisconsin, U.S.A.

Perez, G.H. (2007). Winter and summer soybean growth in southern Cali Rornia. Agronomy Journal. 62: 118-120.

Pirdashti, J. M.H. and Y. Yaghoubian (2014). The combined effect of cold and light intensity stress on some morphological and physiological parameters in two soybean (Glycine max L.) cultivars. International J. of Biosciences, 5(3), $189-197$.

Sadeghi, S.M. and S.N. Niyaki (2013). Effects of Planting date and cultivar on the yield and yield components of soybean in north of Iran. ARPN J. of Agri. and Biological Sci. 8(1): 81-85. 
Shen, X., Y. Zhou, L. Duan, Z. Lia, E. Eneji and J. Eli (2010). Silicon effect on photosynthesis and antioxidant parameter or soybean seedling under draught and ultraviolet B radiation J. Plant physion, 167(15): :1248-1252.

Tahir, M. S. Ahmad, M. Ayub, M. Naeem, H. Rehman and M. A. Sarwar (2013). Impact of planting time and silicon levels on yield and yield components of sunflower (Helianthus annuus L.). Pak. J. Life Soc. Sci.,11(1): 60- 64.

Vadez, V. J., D. Berger, T. Warkentin, S. Asseng, P. Ratnakumar, C. P. Rao and M. Abdou Zaman (2012). Adaptation of seed legumes to climate change: A Review. Agron. Sustain. Dev., 3231 -44.

Vasanthi, N. S. M. Lilly and S.A. Raj (2014). Silicon in crop production and crop protection Agriculture Reviews, 35(1):14-23

Yansheng, L. M. Du, Q. Zhang, G. Wang and J. Jin (2014). Planting Date Influences Fresh Pod Yield and Seed Chemical Compositions of Vegetable Soybean Hort. Sci., 49(11):1376-1380.

Yohei, K. R. Yamazaki and K. Katayama (2018). Effects of late planting on soybean yields and yield components in southwestern Japan. Plant Production Sci., 21 (4):339-348. 


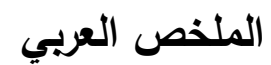 \\ تأثير مواعيد الزراعة والرش الورقي بالسيليكون على إنتاجية فول الصويا}

\section{عصام إسماعيل إسماعيل قنديل' ، أحمد عوني أحمد فرج" ، مهدى إبراهيم عبد اللاه الثابورى '

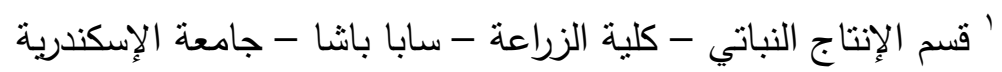 \\ 'المعمل المركزي للمناخ الزراعي - مركز البحوث الزراعية}

أجريت هذه الدراسة في المزرعة البحثية لمحطة البحوث الزراعية بإيتاى البارود خلال الموسم الصيفي لعامي

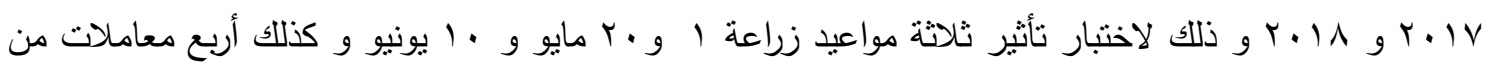

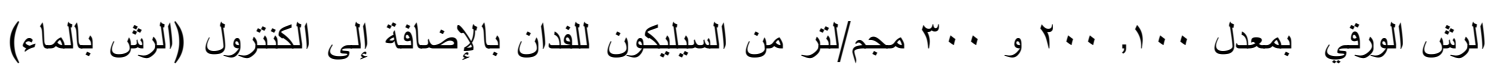

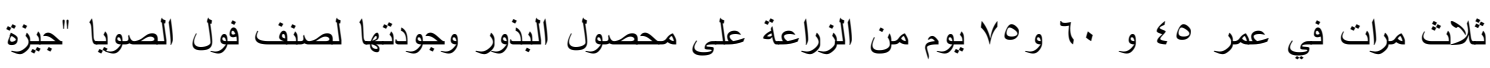

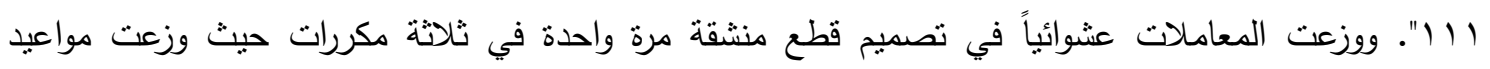
الزراعة في القطع الرئيسية بينما كانت معاملات الرش الورقي للسيلكون في القطع الثقية.

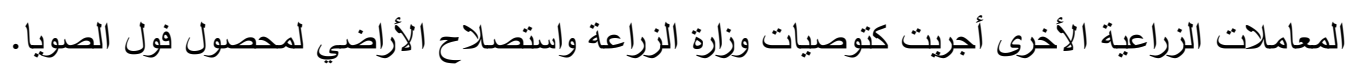

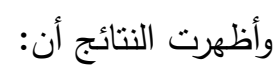

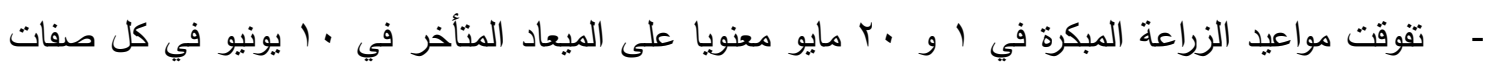

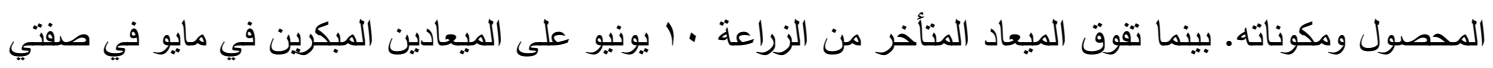
نسبة الزيت و محتوى البذور من السيليكون في كلا الموسمين.

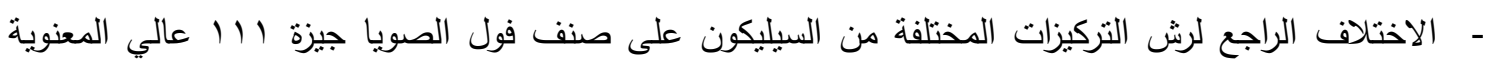
لجميع صفات المحصول ومكوناته في كلا الموسمين عدا نسبة الزيت في الموسم الثاني حيث أدى رش بل بالتركيزات

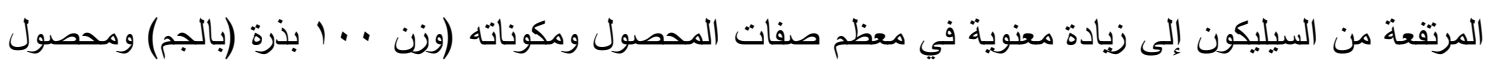

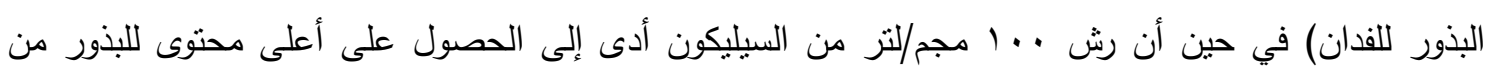

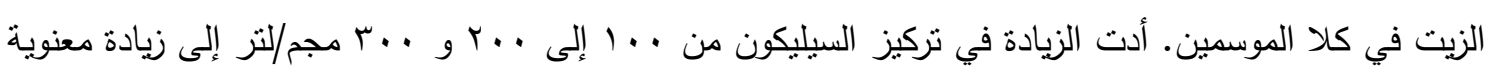

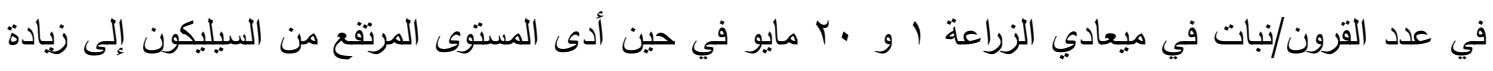

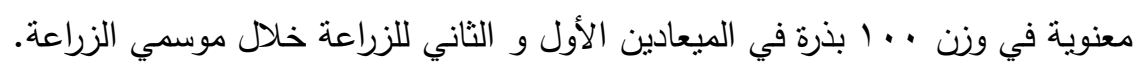

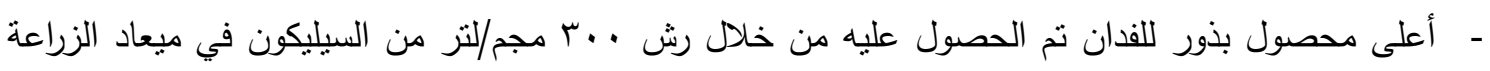

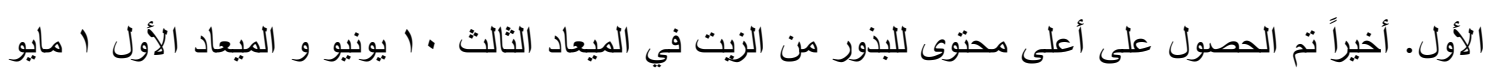

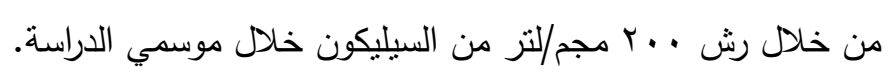

توصى الدراسة بزراعة فول الصويا صنف (جيزة (1) (1) في موعد الزراعة الأول المبكر (الأول من مايو) مع الرش

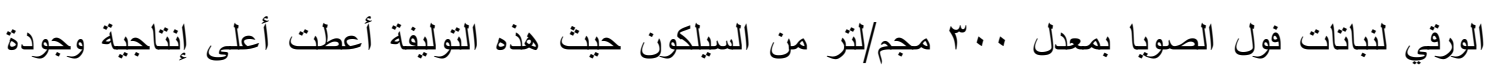
محصول فول الصويا تحت ظروف منطقة إيتاي البارود - محافظة البحيرة. 